\title{
Estimation of red cell folate activity
}

\author{
G. H. SPRAY
}

From the Nuffield Departm?nt of Clinical Medicine, Radcliffe Infirmary, Oxford

SYNOPSIS The conditions described by Hoffbrand, Newcombe, and Mollin (1966) for the estimatio $\overrightarrow{\overrightarrow{\mathrm{D}_{\mathrm{D}}}}$ of red cell folate activity have been confirmed using a different method (Spray, 1964) of micro biological assay with Lactobacillus casei.

In 81 control subjects the levels of folate activity in the red cells were between 80 and $470 \mathrm{~m} \mu \mathrm{g} / \mathrm{m}$ (mean 192), and in plasma between 2.1 and $13 \mathrm{m \mu g} / \mathrm{ml}$ (mean 4.9). In 16 patients with megaloblastif anaemia due to folic acid deficiency, the red cell folate level was between 3 and $74 \mathrm{~m} \mu \mathrm{g} / \mathrm{ml}(\mathrm{mean} 32)$ In 15 of these patients the plasma level was between 0.1 and $1.0 \mathrm{~m} \mu \mathrm{g} / \mathrm{ml}$; in the other patient it was $3.3 \mathrm{~m} \mu \mathrm{g} / \mathrm{ml}$. Subnormal red cell levels were found in only eight out of 29 other patients whose plasma folate level was below $2.0 \mathrm{~m} \mu \mathrm{g} / \mathrm{ml}$. In 26 patients with untreated pernicious anaemia, the red cell folate activity was between 44 and $280 \mathrm{~m} \mu \mathrm{g} / \mathrm{ml}$ (mean 129) and the plasma level was between 1.6 and $19 \mathrm{~m} \mu \mathrm{g} / \mathrm{ml}$ (mean 7.5).

Hoffbrand et al (1966) described a simplified method for estimating folate activity in red cells. They reviewed earlier evidence that this test provides a better assessment of folate status than does serum folate activity and their data supported this conclusion. Some aspects of methods for measuring folate activity remain controversial and the method of Hoffbrand $e t$ al has therefore been examined in detail before using it to study patients.

\section{METHODS}

Blood was collected by venepuncture, using disposable syringes and needles, into plastic tubes containing heparin (Stayne Laboratories Ltd). Soon after collection, $1 \mathrm{ml}$ blood was haemolysed in $9 \mathrm{ml}$ freshly prepared $1 \%(\mathrm{w} / \mathrm{v})$ ascorbic acid solution. The packed cell volume was measured by a micro method on the remaining blood, which was centrifuged and the plasma was removed and ascorbic acid $(5 \mathrm{mg} / \mathrm{ml})$ was added. The haemolysate and plasma were stored at $-20^{\circ} \mathrm{C}$ until required for assay.

After thawing at room temperature and mixing, the haemolysates $(0.5 \mathrm{ml})$ were mixed with $0.9 \mathrm{ml}$ freshly prepared $1 \%$ ascorbic acid solution and $4.4 \mathrm{ml} 0.2 \mathrm{M}$ phosphate buffer $p H$ 6.1 (Spray, 1964) and the volumes were made up to $10 \mathrm{ml}$ with water. The solutions were autoclaved at $15 \mathrm{lb}$ pressure for two and a half minutes, cooled, stirred with glass rods, and centrifuged. The supernatant solutions, which were always clear, were decanted and aliquots $(0.2 \mathrm{ml}$ and $0.4 \mathrm{ml}$ or $0.4 \mathrm{ml}$ and $0.8 \mathrm{ml}$, according to the folate levels expected) were pipetted into each of four assay tubes. The volumes were made up to $1 \mathrm{ml}$ with water and the folate activity was estimated as described previously (Spray, 1964). The folate activity in plasma was estimated in the same wa as for serum (Spray, 1964). In 10 instances, plasma an serum from the same samples of blood were assayed and the results were almost identical. The red cell folat activity was calculated from the whole blood and plasma values as described by Hoffbrand et al (1966).

\section{LABORATORY RESULTS}

FOLATE ACTIVITY OF DIFFERENT AMOUNTS OF WHOLE BLOOD EXTRACTS There was no consistent trend i the results from 15 samples with increasing volumes of extract (Table I).

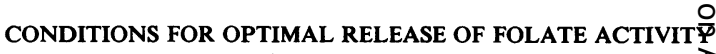
IN HAEMOLYSATES These concern incubation and the packed cell volumes of the samples of blood.

Incubation Toennies, Usdin, and Phillips (1956) first showed that the folate activity of haemolysates of whole blood was higher than those of the plasme and washed red cells measured separately. Therefore haemolysates, the $p \mathrm{H}$ of which was about 3.9 , were incubated at $37^{\circ} \mathrm{C}$, but there were no marke? changes in the folate activity. Some samples werब incubated after the addition of ascorbic acid solutio $\vec{q}$ and buffer, and dilution, when the $p \mathrm{H}$ of the mix tures was about 6.0. Again there was no apparen席 effect on the folate activity (Table II).

Plasma The packed cell volumes of eight samples of blood were artificially increased to about $70 \%$ and reduced to between 11 and $16 \%$. There was 
TABLE I

APPARENT FOLATE ACTIVITY OF WHOLE BLOOD USING DIFFERENT AMOUNTS OF WHOLE BLOOD EXTRACTS

Experiment No.

Blood No.

Whole Blood Extract $(\mathrm{ml})$ in $5 \mathrm{ml}$ Medium

\begin{tabular}{llll}
\hline 0.1 & 0.2 & 0.4 & 0.8 \\
\hline Apparent Folate Activity $(\mathrm{m} \mathrm{\mu g} / \mathrm{ml})$ & &
\end{tabular}

\begin{tabular}{|c|c|c|c|c|c|}
\hline 1 & $\begin{array}{l}1 \\
2\end{array}$ & $\overline{-}$ & $\begin{array}{l}73 \\
59\end{array}$ & $\begin{array}{l}76 \\
56\end{array}$ & $\begin{array}{l}78 \\
62\end{array}$ \\
\hline 2 & $\begin{array}{l}3 \\
4 \\
5\end{array}$ & $\frac{120}{120}$ & $\begin{array}{r}130 \\
50 \\
110\end{array}$ & $\begin{array}{r}140 \\
58 \\
120\end{array}$ & $\begin{array}{r}140 \\
62 \\
140\end{array}$ \\
\hline 3 & $\begin{array}{l}6 \\
7 \\
8\end{array}$ & $\begin{array}{r}140 \\
80 \\
62\end{array}$ & $\begin{array}{r}140 \\
72 \\
70\end{array}$ & $\begin{array}{r}140 \\
65 \\
78\end{array}$ & $\begin{array}{r}150 \\
69 \\
77\end{array}$ \\
\hline 4 & $\begin{array}{r}9 \\
10\end{array}$ & $\begin{array}{l}92 \\
54\end{array}$ & $\begin{array}{l}30 \\
46\end{array}$ & $\begin{array}{l}94 \\
50\end{array}$ & $\begin{array}{l}90 \\
42\end{array}$ \\
\hline 5 & $\begin{array}{l}11 \\
12 \\
13\end{array}$ & $\begin{array}{r}80 \\
100 \\
60\end{array}$ & $\begin{array}{l}80 \\
80 \\
62\end{array}$ & $\begin{array}{l}82 \\
80 \\
55\end{array}$ & $\begin{array}{l}96 \\
84 \\
54\end{array}$ \\
\hline 6 & $\begin{array}{l}14 \\
15\end{array}$ & $\begin{array}{l}100 \\
100\end{array}$ & $\begin{array}{r}80 \\
110\end{array}$ & $\begin{array}{l}82 \\
96\end{array}$ & $\begin{array}{l}100 \\
110\end{array}$ \\
\hline
\end{tabular}

TABLE II

EFFECT OF INCUBATION ON THE FOLATE ACTIVITY OF WHOLE BLOOD HAEMOLYSATES

Experiment No. Blood No. Folate Activity $(\mathrm{m \mu g} / \mathrm{ml})$ of Whole Blood from Haemolysates when

\begin{tabular}{|c|c|c|c|c|c|}
\hline & & \multirow{3}{*}{ Fresh } & \multirow{2}{*}{\multicolumn{2}{|c|}{ Incubated at $37^{\circ} \mathrm{C}$ for }} & \multirow{3}{*}{$\begin{array}{l}\text { Incubated at } 37^{\circ} \mathrm{C} \text { for Two Hours after } \\
\text { Mixing with Ascorbic Acid and Buffer }\end{array}$} \\
\hline & & & & & \\
\hline & & & Two Hours & $18-24$ Hours & \\
\hline 1 & $\begin{array}{l}1 \\
2 \\
3\end{array}$ & $\begin{array}{r}140 \\
54 \\
120\end{array}$ & $\begin{array}{r}140 \\
58 \\
100\end{array}$ & I & $\begin{array}{r}130 \\
52 \\
92\end{array}$ \\
\hline 2 & $\begin{array}{l}4 \\
5 \\
6 \\
7\end{array}$ & $\begin{array}{r}81 \\
100 \\
180 \\
91\end{array}$ & $\begin{array}{r}91 \\
110 \\
180 \\
-\end{array}$ & $\begin{array}{l}- \\
-\end{array}$ & $\begin{array}{r}91 \\
120 \\
180 \\
98\end{array}$ \\
\hline 3 & $\begin{array}{l}8 \\
9\end{array}$ & $\begin{array}{l}60 \\
92\end{array}$ & $\begin{array}{l}61 \\
96\end{array}$ & - & $\begin{array}{r}56 \\
100\end{array}$ \\
\hline 4 & $\begin{array}{l}10 \\
11 \\
12\end{array}$ & $\begin{array}{l}87 \\
72 \\
99\end{array}$ & $\begin{array}{r}86 \\
62 \\
100\end{array}$ & $\begin{array}{l}84 \\
59 \\
98\end{array}$ & $\begin{array}{l}74 \\
54 \\
98\end{array}$ \\
\hline 5 & $\begin{array}{l}13 \\
14\end{array}$ & $\begin{array}{l}50 \\
35\end{array}$ & - & $\begin{array}{l}48 \\
38\end{array}$ & - \\
\hline
\end{tabular}

little difference between the red cell folate activities calculated from the results on haemolysates of the original blood and of the altered samples (Table III).

Red cells from normal subjects and patients with vitamin $B_{12}$ or folic acid deficiency were washed with $0.9 \% \mathrm{NaCl}$ solution and were then mixed with plasma of another type. There were no marked differences between the red cell folate activities using different types of plasma (Table IV).

STORAGE OF SAMPLeS The folate activities of 14 haemolysates, in three batches, were measured when the haemolysates were fresh and after they had been stored at $-20^{\circ} \mathrm{C}$. After four weeks' storage the mean value was $97 \%$ of that when the samples were fresh; after eight weeks it was $95 \%$ and after 12 weeks, $96 \%$. The storage of blood in other ways was not studied because all samples were processed soon after collection.

ACCURACY OF THE METHOD This was tested by means of recovery experiments and reproducibility.

Recovery experiments The recovery of added pteroylglutamic acid was measured from haemolysates of 15 samples of blood. When the equivalent of $25 \mathrm{~m} \mu \mathrm{g} / \mathrm{ml}$ blood was added, the mean recovery 
TABLE III

RED CELL FOLATE ACTIVITY BEFORE AND AFTER ARTIFICIAL CHANGES IN THE PACKED CELL VOLUME OF BLOOD Experiment No. Blood No.

Red Cell Folate Activity ( $\mathrm{m} \mu \mathrm{g} / \mathrm{ml})$

\begin{tabular}{ccccc} 
& & Original Blood & PCV Reduced & PCV \\
\cline { 3 - 5 } & 1 & 110 & 120 & 110 \\
& 1 & 230 & 220 & 230 \\
2 & 3 & 180 & 210 & 180 \\
& 4 & 240 & 230 & 250 \\
3 & 5 & 160 & 180 & 160 \\
& 6 & 170 & 200 & 160 \\
& 7 & 220 & 240 & 240
\end{tabular}

TABLE IV

\begin{tabular}{|c|c|c|c|c|}
\hline \multirow{3}{*}{ Experiment No. } & \multicolumn{4}{|c|}{ EFFECT OF PLASMA FROM DIFFERENT TYPES OF SUBJECT ON RED CELL FOLATE ACTIVITY } \\
\hline & \multirow{2}{*}{ Red Cells } & Normal & $\begin{array}{l}\text { Vitamin } B_{15-} \\
\text { deficient }\end{array}$ & $\begin{array}{l}\text { Folic } A \\
\text { deficien }\end{array}$ \\
\hline & & \multicolumn{3}{|c|}{ Red Cell Folate Activity $(m \mu g / m l)$} \\
\hline 1 & $\begin{array}{l}\text { Normal } \\
\text { B }_{12} \text {-deficient } \\
\text { Folate-deficient }\end{array}$ & $\begin{array}{r}280 \\
87 \\
19\end{array}$ & $\begin{array}{l}280 \\
120 \\
-\end{array}$ & $\frac{250}{29}$ \\
\hline 2 & $\begin{array}{l}\text { Normal } \\
\text { Folate-deficient }\end{array}$ & $\begin{array}{r}380 \\
29\end{array}$ & - & $\begin{array}{r}320 \\
36\end{array}$ \\
\hline 3 & $\begin{array}{l}\text { Normal } \\
\text { B }_{12} \text {-deficient }\end{array}$ & $\begin{array}{l}120 \\
190\end{array}$ & $\begin{array}{l}110 \\
170\end{array}$ & - \\
\hline 4 & $\begin{array}{l}\text { Normal } \\
\text { B }_{12} \text {-deficient } \\
\text { Folate-deficient }\end{array}$ & $\begin{array}{r}260 \\
280 \\
51\end{array}$ & $\begin{array}{l}250 \\
270 \\
-\end{array}$ & $\frac{270}{62}$ \\
\hline
\end{tabular}

was $28.5 \mathrm{~m} \mu \mathrm{g}$ (SD 11.2); with $50 \mathrm{~m} \mu \mathrm{g} / \mathrm{ml}$, the mean recovery was $54 \cdot 1$ (SD 8.8). The lower accuracy with $25 \mathrm{~m} \mu \mathrm{g} / \mathrm{ml}$ is due to two aberrant recoveries, $7 \cdot 5$ and $59 \mathrm{~m} \mu \mathrm{g}$ respectively, from haemolysates of which the folate activity was over four times that of the pteroylglutamic acid added; the remaining values were between 18 and $36 \mathrm{~m} \mu \mathrm{g}$.

Reproducibility To measure the variation of duplicated results, the difference between each pair is expressed as a percentage of their mean. Duplicate haemolysates from 29 samples of blood were assayed in the same assays in nine batches; the variation was between 0.0 and $24 \%$ (mean $6.3 \%$ ). When duplicate haemolysates from 44 samples of blood were assayed in consecutive assays, in nine batches, the variation was $0.0-40 \%$ (mean $10 \%$ ). The plasma corresponding to 26 of these haemolysates (six batches) was also assayed twice, in the same assays as the haemolysates. The variation in the duplicate red cell folate activities was between 0.0 and $24 \%$ (mean $9.9 \%$ ). The variation of the results on plasma was $0.0-26 \%$ (mean $7.2 \%$ ).

\section{RESULTS IN CONTROL SUBJECTS AND PATIENTS}

CONTROL SUBJECTS In 81 healthy subjects, 42 men and 39 women aged between 16 and 63 who wereo members of the hospital staff the values for red cell folate activity were between 80 and $470 \mathrm{~m} \mu \mathrm{g} / \mathrm{ml}$ ? (mean 192, standard deviation 68) and for plasma folate activity, between $2 \cdot 1$ and $13 \mathrm{~m} \mu \mathrm{g} / \mathrm{ml}$ (mean 4.9)을. (Table V). There was a significant correlation be-̃̄ tween the results from red cells and plasma $(r=\Omega$ $0.63, \mathrm{P}<0.001)$. The distribution of the red cell $\tilde{O}$ levels appeared to be normal; that of the plasma levels was skewed, but the logarithms were normallyo distributed. On this basis the $95 \%$ confidence limit $\$ 0$ of the plasma levels were $2 \cdot 1-9.8 \mathrm{~m} \mu \mathrm{g} / \mathrm{ml}$.

FOLIC ACID DEFICIENCY Sixteen patients with megaloblastic anaemia apparently due to folic acido deficiency were studied. The folate levels in the red? cells were between 3 and $74 \mathrm{~m} \mu \mathrm{g} / \mathrm{ml}$, and in plasmao between 0.1 and $1.0 \mathrm{~m} \mu \mathrm{g} / \mathrm{ml}$ except in one patient, an alcoholic whose diet had been inadequate, in 
TABLE V

\begin{tabular}{|c|c|c|c|c|c|c|c|}
\hline \multirow{3}{*}{ Group } & ASMA Al & D CELI & E LEVEL & ONTRO & ECTS ANI & IENTS & \\
\hline & \multirow[t]{2}{*}{$\begin{array}{l}\text { No. of } \\
\text { Subjects }\end{array}$} & \multicolumn{2}{|c|}{$\begin{array}{l}\text { Plasma Folate Activity } \\
(\mathrm{m} \mu \mathrm{g} / \mathrm{m} l)\end{array}$} & \multicolumn{2}{|c|}{$\begin{array}{l}\text { Red Cell Folate Activity } \\
(m \mu g / m l)\end{array}$} & \multicolumn{2}{|c|}{$\begin{array}{l}\text { Serum Vitamin } B_{12}{ }^{1} \\
(\mu \mu g / m l)\end{array}$} \\
\hline & & Mean & Range & Mean & Range & Mean & Range \\
\hline Control subjects & 81 & $4 \cdot 9$ & $2 \cdot 1-13$ & 192 & $80-470$ & \multicolumn{2}{|c|}{ Not determined } \\
\hline $\begin{array}{l}\text { Folic acid deficiency } \\
\text { Megaloblastic anaemia } \\
\text { With plasma folate } \\
\text { below } 2.0 \mathrm{~m} \mu \mathrm{g} / \mathrm{ml}\end{array}$ & $\begin{array}{l}16 \\
29\end{array}$ & 0.8 & $0 \cdot 1-3 \cdot 3$ & 103 & 3- 74 & 281 & $70-520$ \\
\hline $\begin{array}{l}\text { Vitamin } B_{12} \text { deficiency } \\
\text { Untreated pernicious } \\
\text { anaemia }\end{array}$ & 26 & $7 \cdot 5$ & $1 \cdot 6-19$ & 129 & $44-280$ & 48 & 5- 95 \\
\hline Other causes & 8 & $9 \cdot 1$ & $3 \cdot 5-23$ & 174 & $38-300$ & 48 & $0-100$ \\
\hline
\end{tabular}

${ }^{1}$ Assayed with Lactobacillus leichmannii as test organism (Spray, 1955)

whom the value was $3.3 \mathrm{~m} \mu \mathrm{g} / \mathrm{ml}$. This result was from a sample obtained after the patient had been in hospital, taking an improved diet, for two days. Before admission her serum folate level was 1.3 $\mathrm{m} \mu \mathrm{g} / \mathrm{ml}$; five days later it was again $1.3 \mathrm{~m} \mu \mathrm{g} / \mathrm{ml}$. There was a statistically significant correlation between haemoglobin concentration and red cell folate level in the 16 patients $(r=0.654,0.01>P>$ 0.001 ), in agreement with the findings of Hoffbrand et al (1966). Three of the patients had subnormal serum vitamin $B_{12}$ levels, but two of these three were shown to absorb vitamin $B_{12}$ normally.

Twenty-nine other patients were studied, either because their serum folate levels were below $2 \cdot 0$ $\mathrm{m} \mu \mathrm{g} / \mathrm{ml}$ or because they were thought on clinical grounds to have folic acid deficiency. All except one had normal serum vitamin $\mathbf{B}_{12}$ levels. The red cell folate levels were between 29 and $240 \mathrm{~m} \mu \mathrm{g} / \mathrm{ml}$, the results in eight patients being below the normal range. The plasma values were between 0.4 and 1.9 $\mathrm{m} \mu \mathrm{g} / \mathrm{ml}$. These patients had a variety of conditions, including malabsorption (7 patients), iron deficiency (5), treatment with antiepileptic drugs (4), neurological disorders and Crohn's disease ( 3 each), and dietary deficiency, hepatic coma, chronic lymphatic leukaemia, lymphoblastic medullary reticulosis, uterine fibroids, tuberculosis, and sideroblastic anaemia (1 each). Twenty-one were anaemic for reasons other than folate deficiency; it is therefore impossible to analyse the results in detail. However, reports were available on the appearance of the bone marrow in 15 patients. Of six whose bone marrow was normoblastic, only one had a subnormal red cell folate level, compared with four subnormal results among the nine who showed early megaloblastic changes.

VITAMIN B 12 DEFICIENCY There were 26 patients with untreated pernicious anaemia, five who had had a partial gastrectomy, two who had had ileal resections, and one with jejunal diverticulosis. All had subnormal serum vitamin $\mathbf{B}_{12}$ levels. The red cell folate concentrations were between 38 and 300 $\mathrm{m} \mu \mathrm{g} / \mathrm{ml}$ and the plasma folates levels between 1.6 and $23 \mathrm{~m} \mu \mathrm{g} / \mathrm{ml}$. There was a significant correlation between the levels in the red cells and the plasma $(\mathrm{r}=0.558, \mathrm{P}<0.001)$. In the 26 patients with pernicious anaemia, red cell folate levels were between 44 and $280 \mathrm{~m} \mu \mathrm{g} / \mathrm{ml}$, with a mean of 129 which was significantly lower than the normal mean $(t=$ $4.27, \mathrm{P}<0.001$ ). Only one value fell below the normal range at the $95 \%$ probability level, although six $(23 \%)$ were below the observed normal range. The results in plasma were between 1.6 and $19 \mathrm{~m} \mu \mathrm{g} / \mathrm{ml}$ (mean 7.5). No correlation was found between haemoglobin concentration and red cell folate level in these 26 patients $(r=0 \cdot 15, P>0 \cdot 1)$.

\section{DISCUSSION}

The results confirm the conditions described by Hoffbrand et al (1966) for the assay of folate activity in whole blood and red cells. Incubation of haemolysates was unnecessary for maximal release of folate activity. The relative volumes of plasma and red cells could be varied widely without affecting the red cell folate values. Plasma from patients with vitamin $B_{12}$ or folate deficiency was as effective as normal plasma in releasing folate activity in haemolysates. Comparable results were obtained using between 0.1 and $0.8 \mathrm{ml}$ of whole blood extracts in $5 \mathrm{ml}$ of assay medium. The accuracy of the estimations was similar to that reported by Hoffbrand et al (1966). Haemolysates in $1 \%$ ascorbic acid solution were stored for up to 12 weeks without loss of activity.

The values from control subjects are lower than those found by Hoffbrand et al (1966), presumably 
because of the different conditions used for the assay of folate activity. A similar difference was reported between serum folate values (Waters and Mollin, 1961; Spray, 1964). However, the mean value for plasma in this study was $4.9 \mathrm{~m} \mu \mathrm{g} / \mathrm{ml}$, compared with $7.8 \mathrm{~m} \mu \mathrm{g} / \mathrm{ml}$ for serum previously, using the same method of estimation. No explanation has been found for this difference; the lowest values were the same in both series. Red cell and plasma values of 64 and $0.9 \mathrm{~m} \mu \mathrm{g} / \mathrm{ml}$ respectively were found in a healthy young married woman who was using oral contraceptives; the corresponding results from a second sample two weeks later were 76 and 1.8 $\mathrm{m} \mu \mathrm{g} / \mathrm{ml}$. Eighteen other such women were studied; the mean red cell level from the 19 women was 205 $\mathrm{m} \mu \mathrm{g} / \mathrm{ml}$ (range 70-360) and the mean plasma level was $6.2 \mathrm{~m} \mu \mathrm{g} / \mathrm{ml}$ (range 1.4-14). Neither mean was significantly different from those for the control subjects but, since the hormones may affect folate levels, the results are not included in the control group; they are quoted to show that occasionally healthy subjects have low folate levels.

Comparatively few patients with megaloblastic anaemia due to folic acid deficiency have been available for study. However, the results support the suggestion that red cell folate provides a better assessment of folate status than does serum folate. Unequivocally low red cell levels were found in most of these patients, but $21(72 \%)$ of 29 other patients whose serum folate level was below 2.0 $\mathrm{m} \mu \mathrm{g} / \mathrm{ml}$ had normal red cell levels. None of the values in patients with folate-deficient megaloblastie anaemia were within the observed normal range: but two were within the normal range at the $95 \%$ probability level. This is similar to the ranges foung by Hoffbrand et al (1966), whose highest value i⿱ megaloblastic anaemia due to folate deficiency was $143 \mathrm{~m} \mu \mathrm{g} / \mathrm{ml}$, compared with an observed lower limp of the control range of $166 \mathrm{~m} \mu \mathrm{g} / \mathrm{ml}$.

Only one of the patients with untreated pernicious anaemia had an unequivocally subnormal red ceH folate level, in contrast to the low levels found $i \vec{p}$ $63 \%$ of 46 patients by Hoffbrand et al (1966) Nevertheless, the mean value in the present series was significantly lower than the mean for the contrab subjects. The lack of correlation between haemo' globin concentration and red cell folate level is also contrary to earlier findings, but the mean value fof plasma was higher than the normal mean, in agree ment with other reports.

I thank Dr Sheila Callender for advice on the clinicä aspects of the study. Dr Callender and Drs F. G. Boltor, R. P. Britt, A. A. Sharp, and R. A. Sladden kindly senf specimens and haematological data on the patients. I anf grateful to Miss Susan Parker for technical assistance.

\section{REFERENCES}

Hoffbrand, A. V., Newcombe, B. F. A., and Mollin, D. L. (1966 J. clin. Path., 19, 17.

Spray, G. H. (1955). Clin. Sci., 14, 661.

- (1964). J. clin. Path., 17, 660.

Toennies, G., Usdin, E., and Phillips, P. M. (1956). J. biol. Chem., 22 855.

Waters, A. H., and Mollin, D. L. (1961). J. clin. Path., 14, 335. 